Works of the Faculty of Forestry

University of Sarajevo

No. 2, 2018 (1-16)

UDK 630*23:582.475(234.422 Bjelašnica)

\title{
REGENERATION OF FIR IN DIFFERENTLY STRUCTURED STANDS OF BEECH AND FIR FORESTS (WITH SPRUCE) ON BJELAŠNICA
}

\section{Podmlađivanje jele u različito strukturiranim sastojinama šuma bukve i jele (sa smrčom) na Bjelašnici}

\author{
Sead Ivojevićn ${ }^{1}$ Osman Mujezinović ${ }^{1}$, Damir Prljača ${ }^{1}$, Kenan Zahirović ${ }^{2}$
}

\begin{abstract}
This document includes research in regeneration of fir in differently structured stands of beech and fir forests (with spruce) on mountain Bjelašnica near Sarajevo. Analysis of fir regeneration in differently structured stands was done by comparison of numbers of units of young fir, per growth category, and by total number of young fir at canopy density degree of $0.7(0.60-0.79)$ and $0.9(0.80-1.00)$, and by mixture ratio - share of fir (spruce) $0.7(60-79 \%)$ and $0.9(80-100 \%)$. Comparisons were done between virgin forest stands of beech and fir (with spruce) on 'Ravna vala', than, two-storied stand where we recorded transition of tree species (beech is dominant in upper growth, while fir is mainly dominant in young growth) on location 'Medvjeđa lokva' and stands of typical uneven aged production forest of beech and fir (with spruce) in direct vicinity of virgin forest stand. Data gathering was done using total measurement method on permanent experimental plots of 1 ha in virgin forest stand and two-storied stand on location 'Medvjeđa lokva' and on circular plots in diameter of $12.62 \mathrm{~m}$. Positions of circular experimental plots were determined by systematic sample in form of grid on intersections of Gauss-Krueger system, in intervals of 100 meters. Grid is laid in three transects of 27 plots each that is spread across forest compartments number: 111, 113, 114 and 115 of Management unit „Igman“, location 'Ravna vala'. We have placed two experimental square plots of 1 ha; one in virgin forest reservation 'Ravna vala' for preservation of assortment, status without human impact (compartment 106, MU „Igman"), and the other in management forest of this area "Medvjeda lokva" (compartment 117, MU „Igman”) for specific structure of assortment. Square 1ha plots were divided by grid of squares 10 x $10 \mathrm{~m}$ into 100 small plots.
\end{abstract}

Key words: fir, regeneration, structured, canopy density degree, mixture ratio.

\section{INTRODUCTION - Uvod}

According to preliminary results of the Second forest inventory in Bosnia and Herzegovina (2006 - 2009) out of total area of all high forests $(1,652,400$ ha), $42.5 \%$

\footnotetext{
${ }^{1}$ Faculty of Forestry, University of Sarajevo, Zagrebačka 20, 71000 Sarajevo, Bosnia and Herzegovina

${ }^{2} \mathrm{PE}$ „ŠPD ZDK“ Itd Zavidovići, Alije Izetbegovića 25, 72220 Zavidovići, Bosnia and Herzegovina, PU „Šumarija“ Vareš
} 
is covered by conifer and broadleaved forests in forest area of beech and fir (with spruce). In Federation of Bosnia and Herzegovina, out of total area of high forests $(869,000$ ha) beech and fir forests (with spruce) cover $46 \%$.

According to the same source total volume of usable timber of available high production forests in Bosnia and Herzegovina amounts to $353,599,353 \mathrm{~m}^{3}$. Volume of usable timber of available high production forests in communities of coniferous and mixed forests in forest area of beech and fir (with spruce) is $184,535,411 \mathrm{~m}^{3}$, or 52.19 $\%$ of total volume. Volume of usable timber of fir in these forests is $66,584,166 \mathrm{~m}^{3}$ which makes $18.83 \%$ of total volume in mentioned community. Mean total increment of usable timber of all high forests of production character in Bosnia and Herzegovina amounts to $9,069,660 \mathrm{~m}^{3}$. Mean total increment of fir in these forests amounts to $1,946,530 \mathrm{~m}^{3}$ which points out the share of fir in increment of $21.46 \%$.

Based on mentioned, we can state that beech and fir forests (with spruce) are economically the most significant forest communities in Bosnia and Herzegovina. Besides that, due to specific mixing of species and number of vascular flora, these forests are ecologically the most stable and have significant importance on biodiversity preservation.

European silver fir (Abies alba) is main species of selection forests that in its structure per area unit have trees of different species, heights and diameters. Those forests look equally the same externally. In them, relations between the trees are marked by constant struggle for space in the ground and above ground of those trees that are located on different height levels of the stand and in different horizontal structural distribution. In normal growing stock that is distributed in selection structure, those forests have maximum production and optimal and permanent natural regeneration, and good stability (MATIĆ and others, 2001).

Area of distribution of fir forests and its share out of total area under forests has been reduced in the last 200 years in most European countries. Reasons for this relate to human influnce, through uprooting of trees, excessive exploitation, forcing fastgrowing allochthones species, improper forest management and air pollution (WOLF, 2003). Symptoms are manifesting by falling off of needles, early defoliation and final dying of trees (KRAUSE and others, 1986). Emissions of air pollutants from different industries and social activities have large impact on floral organisms growing in those areas. Main air pollutants are road transport means, heat energy producers, industry and agriculture (WOLF, 2003).

Fir as significant stabilizer-species of our most important forest ecosystems lately focuses attention of large number of European scientists. Reasons should be looked for in hundred-year endangerment of fir as tree species in central European forests, due to changeable habitat conditions and application of management system. Only in 50s of past century we have started to intensively work on improvement of ecological conditions of fir and creation of favorable ecosystems as a road to revitalization of existing communities. One other road that requires long-term observation is to find out vital proveniences (MEKIĆ, 1991). 
Present manner of management on Igman led to the situation interruptions in canopy density was mainly too strong, which caused the intensive inflow of light. Therefore, we have overgrowing with weeds on many surfaces, which almost disabled appearance of natural young growth, and even if it did show up, it was suffocated by large quantities of weed. Therefore, we can say that the most common cause of absence of natural young growth is exactly too strong inflow of light, with all negative consequences (PINTARIĆ, 1970).

\section{RESEARCH AREA AND METHODS - Područje istraživanja i metode}

Research objects in this work were experimental plots of circular shape and experimental plots of rectangular shape.

Positions of experimental plots of circular shape were determined by systematic sample in a form of grid on intersections of Gauss-Krueger system, in intervals of 100 meters. Grid is laid in three transects of 27 plots each that is spread across forest compartments number: 111, 113, 114 and 115 of management unit "Igman", location Ravna vala (Figures 2 and 3.). On intersections of the grid we have placed 81 plots. To determine structural characteristics of assortment we have positioned circular plots of fixed diameter $\mathrm{r}=12.62 \mathrm{~m}$ (area of $500 \mathrm{~m} 2$ ) while, for evaluation of status and quality of natural young trees on same habitats (centers) we used circular plots of fixed diameter $\mathrm{r}=3 \mathrm{~m}(28.27 \mathrm{~m} 2)$ (Figures 2. and 3.).

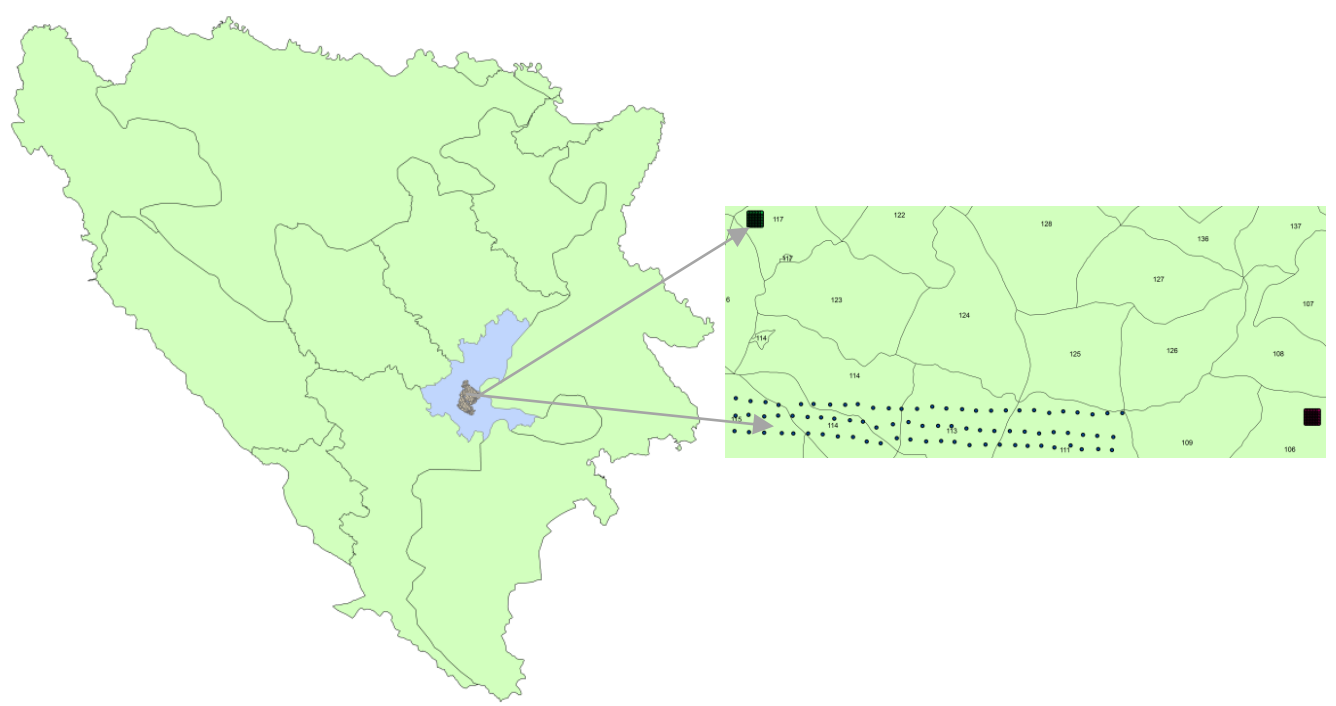

Figure 1. The position of experimental plots in Bosnia and Herzegovina, Canton Sarajevo and MU "Igman"

Slika 1. Položaj eksperimentalnih ploha u Bosni i Hercegovini, Kantonu Sarajevo i GJ „Igman" 
We have placed two experimental plots in a form of a square of tha area (Figures 2. and 3.), out of which, one is in virgin forest reservation 'Ravna vala' for preservation of assortment, status without human impact (compartment 106, management unit "Igman" - Figures 2. and 3.), and the other in management forest of this area 'Medvjeđa lokva' (compartment 117, management unit "Igman" - Figure 2.) for specific structure of assortment. Plots of 1 ha rectangular shape were divided by grid of squares $10 \times 10 \mathrm{~m}$ into 100 small plots (Figure 3). Data gathering on experimental plots was conducted from beginning of summer 2012 to autumn 2014.

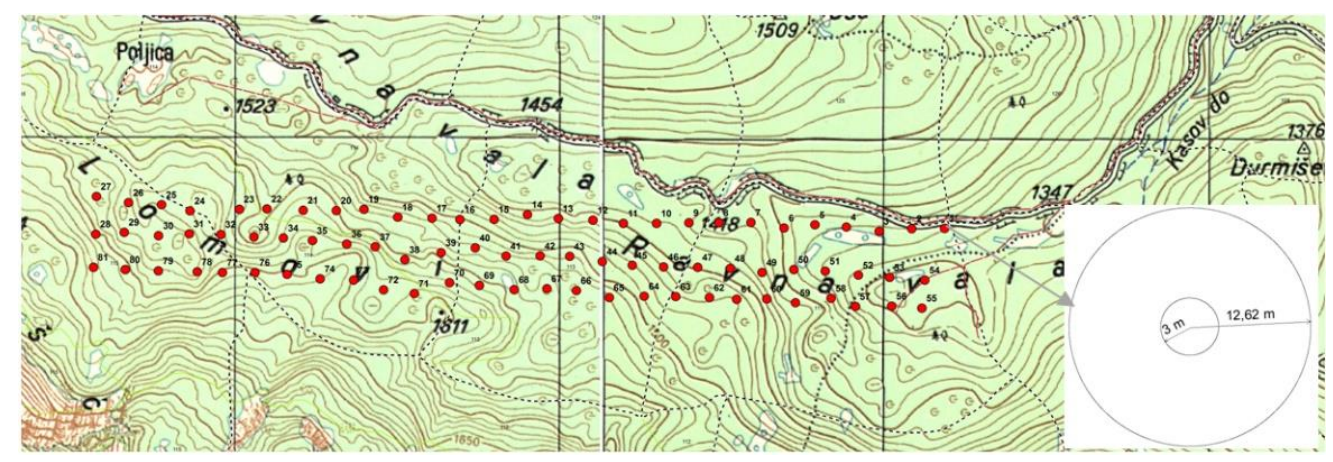

Figure 2. Position and design of circular experimental plots of radius $12.62 \mathrm{~m}$ and $3 \mathrm{~m}$

Slika 2. Položaj i dizajn kružnih eksperimentalnih ploha radijusa 12,62 mi $3 \mathrm{~m}$ 
A

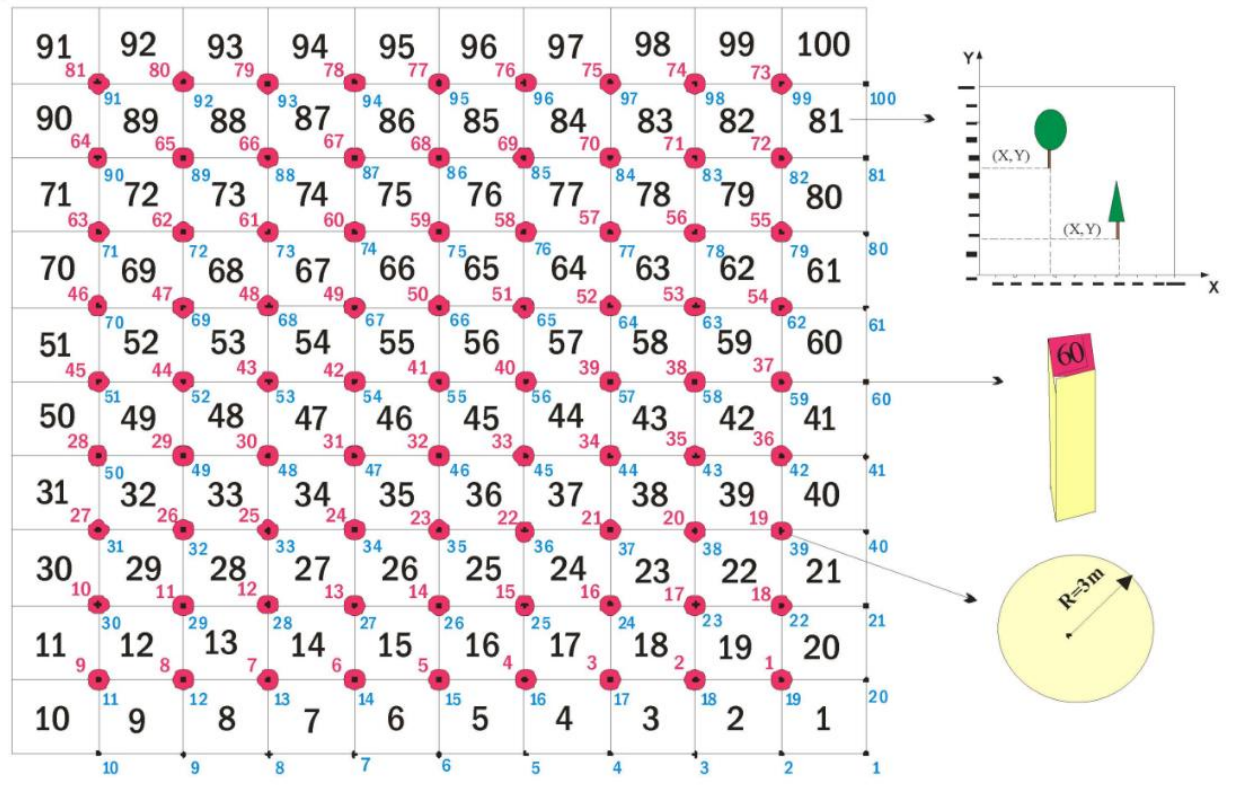

LEGEND:

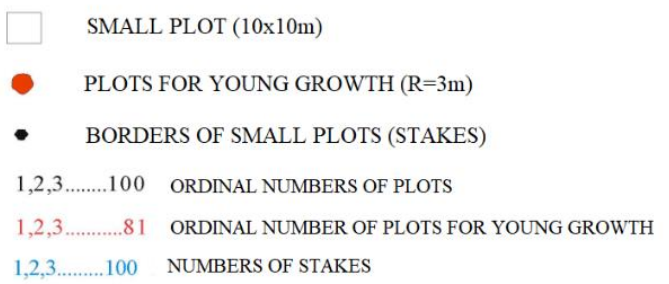

Figure 3. Design of experimental plots of square shape area of 1 ha Slika 3. Dizajn eksperimentalne plohe kvadratnog oblika površine 1 ha

On experimental plots of circular shape, diameter $12.62 \mathrm{~m}$, we have completely measured trees and gathered following data:

- $\quad$ tree species origin,

- $\quad$ tree diameter on height of $1.3 \mathrm{~m}$ (for trees of diameter exceeding $5 \mathrm{~cm}$ ),

- tree height,

- position of the tree in relation to center of the plot via polar method (four dominant trees, in each quadrant one tree on all four sides of the world), 
- $\quad$ current annual increment in diameter (in last 11 years - for dominant trees) and degree of canopy density via Fisheye method.

Fisheye method of determining degree of canopy density includes recording of hemispheric photos (using "fish eye" lenses). Recording of photos was conducted on circle centers to record young trees from the height of $50 \mathrm{~cm}$ (young tree zone). Recorded photos were processed in software Paint net to determine the relation of covered and uncovered parts of the land in assortments' tree tops.

To gain better insight in status of young trees, its numbers, structure, taxation origin, damage and trees with stunted/undergrown canopy (obsolescence), we have recorded young trees on secondary small plots of circular shape, $3 \mathrm{~m}$ radius with common circle centers with plots of $12.62 \mathrm{~m}$ diameter.

Young trees were recorded considering the number and origin to the given species and according to growth was classified into (LOJO and others 2008):

seedling of $0.1-9.9 \mathrm{~cm}$ growth,

young trees of $10.0-49.9 \mathrm{~cm}$ growth,

young trees of $50.0-130.0 \mathrm{~cm}$ growth, and

young trees of diameter at breast height of $0.1-5.0 \mathrm{~cm}$.

Besides these characteristics, young trees were described as per the manner of appearance (individually or in groups), origin (generative or vegetation), trees with stunted/undergrown canopy (obsolescence) (with or without stunted/undergrown canopy (or young growth obsolete or not obsolete)) and damage (damaged or undamaged). For two growth categories of young trees (from 50 to $130 \mathrm{~cm}$ of height and diameter at breast height of 0.1 to $5 \mathrm{~cm}$ ) we have determined growth increment for last 10 years (for all present units of these two categories on each experimental plot).

Experimental square plots (Figure 3) were staked out so that the sides are stretching in direction of main sides of the world. Marking of boundaries of plot $100 \mathrm{x}$ $100 \mathrm{~m}$ and internal division to small plots $10 \times 10 \mathrm{~m}$ was done using wood stakes of dimensions $5 \times 5 \times 50 \mathrm{~cm}$. All small plots within the plot of 1 ha are numbered. With numbering we started from the first border stake of permanent plot ( $1 \mathrm{ha}$ ) that is located in direction of south-east looking from the center of the plot. Small plot on whose corner is the side; the start stake has ordinal number 1 . Number 2 is small plot located to the left of the first small plot and it goes so on until the tenth small plot when we are moving into the second row and it goes on (without interruptions/breaks) in the form of snake all the way to the last small plot number 100. Numbers of small plots are written on the head of the stake with arrows pointing to the small plot origin (Figure 3).

Borders of experimental plots were marked, geo-coded and transferred into Gauss-Krueger coordinate system. Besides that, we staked out centers of circles to determine status of natural young growth and degree of canopy density. On each 
experimental plot we conducted complete measurement of all living standing trees of diameter at breast height above $5 \mathrm{~cm}$.

On all plots were have numbered trees. It has been done for each plot of $10 \mathrm{x}$ $10 \mathrm{~m}$ inside the plot of 1 ha separately. On each plot $(10 \times 10 \mathrm{~m})$ number of trees starts from ordinal number 1. Marks of plots and number of trees are written on aluminum tape (dimensions $2.5 \times 5 \mathrm{~cm}$ ) which is fixed to the tree on a height of $1.8 \mathrm{~m}$ and always on the upper side of the tree. The tape on its upper half has written affiliation to the plot, and under it is number of the tree.

All trees above taxation threshold $\left(\mathrm{d}_{1,3} \geq 5 \mathrm{~cm}\right)$ are marked on height of $1.3 \mathrm{~m}$, on sloped terrain calculating the height of the upper portion of the tree. As we measured two crossed diameters, than trees were marked on all four sides with the mark in shape of circle in radius of $4 \mathrm{~cm}$ by using blue paint or spray. Marks on trees are oriented toward sides of the world.

On experimental plots of 1ha square shapes we have conducted total measurement and gathered following data:

- $\quad$ tree species origin,

- $\quad$ tree diameter on height of $1.3 \mathrm{~m}$ (for trees of diameter exceeding $5 \mathrm{~cm}$ )

- tree height,

- $\quad$ position of the tree in space (orthogonal method),

- $\quad$ degree of canopy density via Fisheye method.

Plot centers for recording of natural young trees were on intersections of grid $10 \times 10 \mathrm{~m}$. Completely positioned 81 circular shape (radius $3 \mathrm{~m}$ ) plot each to measure young trees on both plots of square shape ('Medvjeđa lokva' and Virgin Forest) (Figure 3 ). On experimental plots of square shape, we gathered data on young tree status with the same methodology as on experimental plots of circular shape.

\section{RESULTS - Rezultati}

Analysis of fir regeneration in differently structured stands of beech and fir (with spruce) forests was done by comparison of the number of young firs, per growth categories, and total number of young fir in degree of canopy density of 0.7 (0.60$0.79)$ and $0.9(0.80-1.00)$, and mixture ratio-share of fir (spruce) of $0.7(60-79 \%)$ and $0.9(80-100 \%)$. 
Table 1. Analysis of the variance for the number of young fir of the growth category from 0.1 to $9.9 \mathrm{~cm}$ in height in different structured stands

Tabela 1. Analiza varijanse za brojnost podmlatka jele uzrasne kategorije od 0,1 do 9,9 cm visine u različito strukturiranim sastojinama

\begin{tabular}{|l|c|c|c|c|c|}
\hline \multicolumn{1}{|c|}{$\begin{array}{c}\text { Sources of } \\
\text { variation }\end{array}$} & $\begin{array}{c}\text { Sum of the } \\
\text { squares }\end{array}$ & $\begin{array}{c}\text { Number of } \\
\text { degrees of } \\
\text { freedom }\end{array}$ & $\begin{array}{c}\text { Mid squares - } \\
\text { variances }\end{array}$ & $\begin{array}{c}\text { F - variance } \\
\text { ratio }\end{array}$ & $\begin{array}{c}\text { P - level of } \\
\text { significance }\end{array}$ \\
\hline Between the groups & $3,14473 \mathrm{E} 8$ & 2 & $1,57236 \mathrm{E} 8$ & 29,28 & 0,0000 \\
\hline Inside the groups & $1,22969 \mathrm{E} 9$ & 229 & $5,3698 \mathrm{E} 6$ & & \\
\hline Total (Correction) & $1,54416 \mathrm{E} 9$ & 231 & & & \\
\hline
\end{tabular}

According to Analysis of variance (ANOVA) for the number of young fir of the growth category from 0.1 to $9.9 \mathrm{~cm}$ in height in different structured stands, presented in table above, we can see that observed stands statistically are significantly different per number of units of young fir.

Table 2. Analysis of the variance for the number of young fir of growth category from 10.0 to $49.9 \mathrm{~cm}$ in height in different structured stands

Tabela 2. Analiza varijanse za brojnost podmlatka jele uzrasne kategorije od 10,0 do 49,9 cm visine $u$ različito strukturiranim sastojinama

\begin{tabular}{|l|c|c|c|c|c|}
\hline $\begin{array}{c}\text { Sources of } \\
\text { variation }\end{array}$ & $\begin{array}{c}\text { Sum of the } \\
\text { squares }\end{array}$ & $\begin{array}{c}\text { Number of } \\
\text { degrees of } \\
\text { freedom }\end{array}$ & $\begin{array}{c}\text { Mid squares - } \\
\text { variances }\end{array}$ & $\begin{array}{c}\text { F - variance } \\
\text { ratio }\end{array}$ & $\begin{array}{c}\text { P - level of } \\
\text { significance }\end{array}$ \\
\hline Between the groups & $3,27373 \mathrm{E} 8$ & 2 & $1,63687 \mathrm{E} 8$ & 23,95 & 0,0000 \\
\hline Inside the groups & $1,56522 \mathrm{E} 9$ & 229 & $6,83501 \mathrm{E} 6$ & & \\
\hline Total (Correction) & $1,89259 \mathrm{E} 9$ & 231 & & & \\
\hline
\end{tabular}

According to Analysis of variance (ANOVA) for the number of young fir of growth category from 10.0 to $49.9 \mathrm{~cm}$ in height in different structured stands, it has been determined that observed stands statistically are significantly different per number of young fir of mentioned growth category $(\mathrm{P}<0,05)$.

Table 3. Analysis of the variance for the number of young fir of growth category of height from 50 to $130 \mathrm{~cm}$ in different structured stands

Tabela 3. Analiza varijanse za brojnost podmlatka jele uzrasne kategorije od 50 do $130 \mathrm{~cm}$ visine $u$ različito strukturiranim sastojinama

\begin{tabular}{|l|c|c|c|c|c|}
\hline Sources of variation & $\begin{array}{c}\text { Sum of the } \\
\text { squares }\end{array}$ & $\begin{array}{c}\text { Number } \\
\text { of degrees } \\
\text { of } \\
\text { freedom }\end{array}$ & $\begin{array}{c}\text { Mid squares - } \\
\text { variances }\end{array}$ & $\begin{array}{c}\text { F - } \\
\text { variance } \\
\text { ratio }\end{array}$ & $\begin{array}{c}\text { P - level of } \\
\text { significance }\end{array}$ \\
\hline Between the groups & $1,51086 \mathrm{E} 8$ & 2 & $7,55432 \mathrm{E} 7$ & 79,12 & 0,0000 \\
\hline Inside the groups & $2,18647 \mathrm{E} 8$ & 229 & 954792, & & \\
\hline Total (Correction) & $3,69734 \mathrm{E} 8$ & 231 & & & \\
\hline
\end{tabular}


According to Analysis of variance (ANOVA) for the number of young fir of growth category of height from 50 to $130 \mathrm{~cm}$ in different structured stands, we can see that researched stands statistically are significantly different per number of young growth of analyzed growth category $(\mathrm{P}<0,05)$ at probability of $95 \%$.

Table 4. Analysis of the variance for the number of young fir of the growth category from 0.1 to $5.0 \mathrm{~cm}$ diameter at breast height in different structured stands

Tabela 4. Analiza varijanse za brojnost podmlatka jele uzrasne kategorije od 0,1 do 5,0 cm prsnog prečnika u različito strukturiranim sastojinama

\begin{tabular}{|l|c|c|c|c|c|}
\hline Sources of variation & $\begin{array}{c}\text { Sum of the } \\
\text { squares }\end{array}$ & $\begin{array}{c}\text { Number } \\
\text { of degrees } \\
\text { of } \\
\text { freedom }\end{array}$ & $\begin{array}{c}\text { Mid squares - } \\
\text { variances }\end{array}$ & $\begin{array}{c}\text { F - } \\
\text { variance } \\
\text { ratio }\end{array}$ & $\begin{array}{c}\text { P - level of } \\
\text { significance }\end{array}$ \\
\hline Between the groups & $2,01485 \mathrm{E} 8$ & 2 & $1,00742 \mathrm{E} 8$ & 85,34 & 0,0000 \\
\hline Inside the groups & $2,70334 \mathrm{E} 8$ & 229 & $1,1805 \mathrm{E} 6$ & & \\
\hline Total (Correction) & $4,71818 \mathrm{E} 8$ & 231 & & & \\
\hline
\end{tabular}

Results of Analysis of variance (ANOVA) for the number of young fir of the growth category from 0.1 to $5.0 \mathrm{~cm}$ diameter at breast height in different structured stands, it has been determined that observed stands statistically are significantly different per number of units of young fir of mentioned growth category $(\mathrm{P}<0,05)$ at probability of $95 \%$.

Table 5. Analysis of the variance for the total number of young firs at the canopy density degree of 0.7 in differently structured stands

Tabela 5. Analiza varijanse za ukupnu brojnost podmlatka jele pri stepenu sklopa 0,7 u različito strukturiranim sastojinama

\begin{tabular}{|l|c|c|c|c|c|}
\hline Sources of variation & $\begin{array}{c}\text { Sum of the } \\
\text { squares }\end{array}$ & $\begin{array}{c}\text { Number } \\
\text { of degrees } \\
\text { of } \\
\text { freedom }\end{array}$ & $\begin{array}{c}\text { Mid squares - } \\
\text { variances }\end{array}$ & $\begin{array}{c}\text { F - } \\
\text { variance } \\
\text { ratio }\end{array}$ & $\begin{array}{c}\text { P - level of } \\
\text { significance }\end{array}$ \\
\hline Between the groups & $3,06304 \mathrm{E} 7$ & 2 & $1,53152 \mathrm{E} 7$ & 3,24 & 0,0444 \\
\hline Inside the groups & $3,63632 \mathrm{E} 8$ & 77 & $4,7225 \mathrm{E} 6$ & & \\
\hline Total (Correction) & $3,94263 \mathrm{E} 8$ & 79 & & & \\
\hline
\end{tabular}

Previous table shows the results of Analysis of variance (ANOVA) for the total number of young firs at the canopy density degree of 0.7 in differently structured stands. According to Analysis of variance we can see that researched stands statistically are significantly different per total number of units of young fir in conditions of canopy density degree of 0.7 at probability of $95 \%(\mathrm{P}<0,05)$. 
Table 6. Analysis of the variance for the total number of young fir at the canopy density degree of 0.9 in differently structured stands

Tabela 6. Analiza varijanse za ukupnu brojnost podmlatka jele pri stepenu sklopa 0,9 u različito strukturiranim sastojinama

\begin{tabular}{|l|c|c|c|c|c|}
\hline Sources of variation & $\begin{array}{c}\text { Sum of the } \\
\text { squares }\end{array}$ & $\begin{array}{c}\text { Number } \\
\text { of degrees } \\
\text { of } \\
\text { freedom }\end{array}$ & $\begin{array}{c}\text { Mid squares - } \\
\text { variances }\end{array}$ & $\begin{array}{c}\text { F - } \\
\text { variance } \\
\text { ratio }\end{array}$ & $\begin{array}{c}\text { P - level of } \\
\text { significance }\end{array}$ \\
\hline Between the groups & $1,17918 \mathrm{E} 8$ & 2 & $5,8959 \mathrm{E} 7$ & 12,38 & 0,0000 \\
\hline Inside the groups & $3,83491 \mathrm{E} 9$ & 805 & $4,76387 \mathrm{E} 6$ & & \\
\hline Total (Correction) & $3,95283 \mathrm{E} 9$ & 807 & & & \\
\hline
\end{tabular}

Previous table contains results of Analysis of variance (ANOVA) for the total number of young fir at the canopy density degree of 0.9 in differently structured stands. Level of significance $(\mathrm{P}<0,05)$ shows that researched stands statistically are significantly different per total number of young fir per equal degree of canopy density (0.9).

Table 7. Analysis of the variance for the total number of young fir by the mixture ratio - the share of fir (spruce) 0.7 in differently structured stands

Tabela 7. Analiza varijanse za ukupnu brojnost podmlatka jele pri omjeru smjese-učešću jele (smrče) 0,7 u različito strukturiranim sastojinama

\begin{tabular}{|l|c|c|c|c|c|}
\hline Sources of variation & $\begin{array}{c}\text { Sum of the } \\
\text { squares }\end{array}$ & $\begin{array}{c}\text { Number } \\
\text { of degrees } \\
\text { of } \\
\text { freedom }\end{array}$ & $\begin{array}{c}\text { Mid squares - } \\
\text { variances }\end{array}$ & $\begin{array}{c}\text { F - } \\
\text { variance } \\
\text { ratio }\end{array}$ & $\begin{array}{c}\text { P - level of } \\
\text { significance }\end{array}$ \\
\hline Between the groups & $4,35692 \mathrm{E} 7$ & 1 & $4,35692 \mathrm{E} 7$ & 12,87 & 0,0005 \\
\hline Inside the groups & $4,13088 \mathrm{E} 8$ & 122 & $3,38597 \mathrm{E} 6$ & & \\
\hline Total (Correction) & $4,56658 \mathrm{E} 8$ & 123 & & & \\
\hline
\end{tabular}

According to the results of Analysis of variance (ANOVA), from table above, we can see that management forest and virgin forest stands statistically are significantly different $(\mathrm{P}<0,05)$ per total number of units of young fir in conditions of mixture ratio where fir (spruce) has a share of 0.7 , i.e. where their share in total volume of the stand is 60 to $79 \%$. 
Table 8 . Analysis of the variance for the total number of young fir at the mixture ratio - the share of fir (spruce) 0,9 in differently structured stands

Tabela 8. Analiza varijanse za ukupnu brojnost podmlatka jele pri omjeru smjese - učešću jele (smrče) 0,9 u različito strukturiranim sastojinama

\begin{tabular}{|l|c|c|c|c|c|}
\hline Sources of variation & $\begin{array}{c}\text { Sum of the } \\
\text { squares }\end{array}$ & $\begin{array}{c}\text { Number } \\
\text { of degrees } \\
\text { of } \\
\text { freedom }\end{array}$ & $\begin{array}{c}\text { Mid squares - } \\
\text { variances }\end{array}$ & $\begin{array}{c}\text { F - } \\
\text { variance } \\
\text { ratio }\end{array}$ & $\begin{array}{c}\text { P - level of } \\
\text { significance }\end{array}$ \\
\hline Between the groups & $2,60024 \mathrm{E} 7$ & 1 & $2,60024 \mathrm{E} 7$ & 5,74 & 0,0176 \\
\hline Inside the groups & $7,69662 \mathrm{E} 8$ & 170 & $4,52742 \mathrm{E} 6$ & & \\
\hline Total (Correction) & $7,95665 \mathrm{E} 8$ & 171 & & & \\
\hline
\end{tabular}

Previous table contains results of the Analysis of variance (ANOVA) for the total number of young fir at the mixture ratio - the share of fir (spruce) 0,9 for management forest and virgin forest stands. Level of significance $(\mathrm{P}<0,05)$ confirms that these two stands statistically are significantly different per total number of the young fir in equal mixture ratio at probability of $95 \%$.

Accepting the results of Analysis of variance for the number of individual growth categories of young fir depending on stands of different structural development/growth, we can state that significance of stand structure impact increases with the increase in growth of young fir. Namely, value " $F$ " increases from 29.28 for seedlings to 85.34 for the highest growth category of young fir.

\section{DISCUSSION - Diskusija}

Analysis of regeneration of fir in differently structured stands of virgin forests, 'Medvjeđa lokva' and experimental plots in management forest was done by comparison of determined number of young fir as per growth categories. Virgin forest as representative of status without impact of silvicultural measures, and other two stands as representatives of management forest in which through silvicultural measures we have formed stands of different structure.

Results of the analysis of variance confirm that three observed stands statistically are significantly different per determined number of each growth category of young fir.

When we are considering young units in virgin forest, during decision making on evaluation of regeneration one needs to be careful because young growth is very uneven. Reason for that is that the virgin forest itself is different per growth phases, and in it there are parts where regeneration is not present or is weakly expressed, but also those areas where regeneration is exuberant, which is linked to appearance of ,gaps“openings, clearings in the stand (KLOPČIČ and DIACI, 2009; MIKAC and others, 2009). Mentioned statement is confirmed with the results of this research where we can see that in virgin forest the largest number of units was recorded only in smallest growth 
category, while number of other growth categories is smallest compared to other analyzed stands. Reason for these results we can look for in large number of experimental areas that have had completely full canopy density, while very small number of analyzed areas had smaller degree of canopy density.

Appearance of young fir in management forest has opposite tendency than the appearance of young fir in virgin forest. While in management forests larger clearings (gaps) occurred due to intensive harvest could be a reason for reduction of number of young growth or obstacle in appearances of natural young growth, in virgin forest we have completely different situation where clearings are the main predispositions for renewal (KLOPČIČ and DIACI, 2009; MIKAC and others, 2009). In management forest through silviculture measures we can impact on degree of canopy density i.e. on quantity of available light in layer of young growth. We should not forget that the light is ecological factor on which we can have direct impact with silviculture activities/endeavors (OSTROGOVIĆ and others, 2010).

Observing the results of received dependence of numbers of young fir in differently structured stands, and in different mixture ratios, we can determine that largely the numbers of young fir depends upon the presence of beech in upper growth. However, in conditions of mixture ratio where beech is prevailing, we have recorded the smaller number in each of observed stands, while maximum numbers was determined in mixture ratio of 0.7 (60 to $80 \%$ ) fir (spruce). According to research conducted by UGARKOVIĆ and others (2011) situation with regeneration in fir-beech forests is very sensitive process which is in complex connection with numerous factors. Also, GAŠPERŠIĆ, (1974) emphasizes that on regeneration of fir the large impact is present by biochemical and microbiological processes in humus layer of the soil, connected to quantity of beech i.e. fir litter. The same author in his doctoral dissertation provides explanation in a sense that for regeneration of fir in 'Snežnik-Javornik' forests of beech and fir (in Slovenia - on border with Croatia) bioecological process which cannot be directed, stopped, or accelerated through simple technical processes and for a short time. He further concludes that for natural regeneration of fir, the more important is biological impact than ecological one. Climate impacts are not significant, but the soil type is important. He also claims that the structure of the stand is not in correlation with regeneration, stating that also not important aspects are absolute quantity of growing stock, quantity of light and absolute intensity of harvest in the past. And on the other hand, he states that largely its regeneration is impacted by the mixture of tree species in wood mass of past harvests. Especially he emphasizes errors in mass extermination of beech which results in creation of pure fir stand.

According to statements of ANIĆ, (2007) related to density of young growth and its dependence on periodicity of yield in seed, and that it changes year in and year out, the similar situation is with young growth in height of $50 \mathrm{~cm}$, because mortality of young generation is intense in first years of growth. If into analysis we take only those plants whose height exceeds $50 \mathrm{~cm}$ than it results that status of regeneration of European silver 
fir is better in management and artificially directed stands comparing to virgin forest stand.

In one document, 60 years ago, ŠAFAR, (1957) suggested to us that fir is better and cheaper regenerated by maintaining such habitat and stand circumstances that suite to special biological characteristics of young fir, especially younger growth phases, presence in optimum of air and soil moisture, small microclimate extremes and good physical soil properties. This actually, from the aspect of forest tree growing, tells us that we must not too much and too suddenly open canopy density, but maintain it in a form of more dense vertical and gradual canopy density with regeneration in groups.

\section{CONCLUSIONS - Zaključci}

1. Maximum number of units of all growth categories of young fir has been determined with degree of canopy density of $0.7-0.9$ and mixture ratio of 0.5 beech: 0.5 fir (spruce). Mentioned conditions of coverage of land by tree canopy and mixture ratio of tree species are optimum for regeneration of fir in researched stands.

2. Analysis of regeneration of fir in stands of different structure establishes the statistically significant differences between the number of units of young fir in differently structured stands.

3. Favorable conditions for unobstructed growth and development of individual growth categories of young fir are in stands of different structural growth/development.

4. Optimum conditions for appearance and unobstructed growth and development, for each growth category of young fir, is possible to be ensured by forming regeneration areas on which based on growth of young units, one will grow appropriate stand structure through silvicultural activities.

\section{REFERENCES - Literatura}

ANIĆ, I. (2007): Utjecaj strukture i pomlađivanja na potrajnost šuma bukve i jele te šuma bukve nacionalnog parka Plitvička jezera. Završno izvješće. Zagreb 2007. Str.162. (Impact of structure and regeneration to sustainability of beech and fir forests, and beech forests of national park 'Plitvička jezera'. Final report. Zagreb 2007. Pages 1-62.)

GAŠPERŠIČ, F. (1974): Zakonitosti naravnega pomlajevanja jelovo-bukovih gozđov na visokem Krasu Snežničko-Javorniškega masiva (Properties of natural regeneration of fir-beech forests on high karst of Snežnik-Javornik massif). Institut za gozdno in lesno gospodarstvo, Biotehniška fakulteta Univerze v Ljubljani, 1974. 
Disertacija. Stranica 133. u Šafar, J., 1975: Presjek doktorske disertacije, Šumarski list broj 1-3/1975. str. 91. Zagreb.

KRAUSE, G. H. M., ARNDT, U., BRANDT, C. J., BUCHER, J., KENK, G., MATZNER, E. (1986): Forest decline in Europe; Development and possible causes. Water, Air, and Soil Pollution, 31: 647-668.

KLOPČIČ, M., DIACI, J. (2009): Gap characteristics and development of regeneration following a blowdown in old-growth forest remnant Pečka. In: Prašumski ekosustavi dinarskog krša i prirodno gospodarenje šumama u Hrvatskoj. Ed. Matić, S, Anić, I. HAZU Zagreb: 55-70.

LOJO, A., BEUS, V., MEKIĆ, F., KOPRIVICA, M., MUSIĆ, J., TREŠTIĆ., T., BALIĆ, B., ČABARAVDIĆ, A., HOČEVAR, M. (2008): Metodika druge inventure šuma na velikim površinama u Bosni i Hercegovini $=$ Methodology of Second Forest Inventory on large areas in B\&H / - Radovi Šumarskog fakulteta u Sarajevu, Sarajevo, Posebna izdanja br. 20, sv. 1, 2008. - str. 1-156.

MATIĆ, S., ORŠANIĆ, M., ORLIĆ, S., ANIĆ, I. (2001): Sjemenarstvo, rasadnička proizvodnja i šumske kulture obične jele (Abies alba Mill.), Monografija Obična jela (Abies alba Mill.) u Hrvatskoj, Akademija šumarskih znanosti, Zagreb. (2001: Seedling production, nursery production and forest species of European silver fir (Abies alba Mill.), Monography European silver fir (Abies alba Mill.) in Croatia, Academy of forestry sciences, Zagreb.)

MEKIĆ, F. (1991): Morfološke karakteristike petogodišnjih sadnica jele (Abies alba Mill.) sa devet lokaliteta u BiH, Univerzitet u Beogradu, Glasnik Šumarskog fakulteta, Beograd br. 73. (1991: Morphological characteristics of five-year old seedlings of European silver fir (Abies alba Mill.) from nine locations in $\mathrm{B} \& \mathrm{H}$, University in Belgrade, Magazine of Forestry Faculty, Belgrade no. 73)

MIKAC, S., ROZENBERGAR, D., ANIĆ, I., DIACI, J. (2009): Značajke podmlađivanja u progalama dinarskih bukovo - jelovih prašuma. In: Prašumski ekosustavi dinarskog krša i prirodno gospodarenje šumama u Hrvatskoj. Ed. Matić, S, Anić, I. HAZU Zagreb: 41-54. (2009: Characteristics of regeneration in clearings of Dinaride beech-fir virgin forests. In: Virgin forest ecosystems of Dinaride karst and natural management of forests in Croatia. Ed. Matić, S, Anić, I. HAZU Zagreb: 41 54.)

OSTROGOVIĆ, M. Z., SEVER, K., ANIĆ, I. (2010): Utjecaj svjetla na prirodno pomlađivanje hrasta lužnjaka (Quercus robur L.) u park - šumi Maksimir u Zagrebu. Šumarski list, 134 (3-4): 115-123. (2010: Impact of light on natural regeneration of common oak (Quercus robur L.) in park - forest Maksimir in Zagreb. Forestry magazine, 134 (3-4): 115-123)

PINTARIĆ, K. (1970): Uticaj zasjenjenosti i pripreme zemljišta na pojavu prirodnog podmlatka jele u prebornim šumama jele, smrče i bukve na Igmanu, Radovi Šumarskog fakulteta i Instituta za šumarstvo u Sarajevu, Godina XIII (1968), Knjiga 13, sveska 3. (1970: Impact of shadow cover and preparation of soil to 
appearance of natural young fir in selection forests of fir, spruce and beech on Igman, Documents of Forestry Faculty and Institute for Forestry in Sarajevo, Year XIII (1968), Book 13, item 3.)

ŠAFAR, J. (1957): O podmlađivanju jele na planinskom području Hrvatske. Šumarski list broj 11-12 1957. str. 403-417. Zagreb. (On regeneration of fir on mountainous area of Croatia. Forestry magazine 11-12 1957. pages 403-417. Zagreb)

UGARKOVIĆ, D., TIKVIĆ, I., SELETKOVIĆ, Z., ORŠANIĆ, M., SELETKOVIĆ, I., BLAŽNIKOV, M., MRKONJIĆ-FUKA, M., REDŽEPOVIĆ, S. (2011): Neke mikrobiološke značajke tala i prirodno pomlađivanje šumskih otvora oštećenih šumskih ekosustava obične jele (Abies alba Mill.) u Gorskom Kotaru. Šumarski list br. 3-4, CXXXV (2011), 99-111. Zagreb. (2011: Some micro-biological properties of soils and natural regeneration of forest openings of damaged forest ecosystems of European silver fir (Abies alba Mill.) in Gorski Kotar. Forestry magazine no. 3-4, CXXXV (2011), 99-111. Zagreb)

WOLF, H. (2003): EUFORGEN Technical Guidelines for genetic conservation and use for silver fir (Abies alba Mill.). International Plant Genetic Resources Institute, Rome, Italy, 6 pages, Rome.

\section{SAŽETAK}

U ovom radu vršena su istraživanja podmlađivanja jele $u$ različito strukturiranim sastojinama šuma bukve i jele (sa smrčom) na planini Bjelašnici nedaleko od Sarajeva. Analiza podmlađivanja jele $u$ različito strukturiranim sastojinama izvršena je poređenjem broja jedinki podmlatka jele, po uzrasnim kategorijama, te ukupne brojnosti podmlatka jele pri stepenu sklopa od $0,7(0,60-0,79)$ i $0,9(0,80-1,00)$, te omjerom smjese - učešćem jele (smrče) $0,7(60-79 \%)$ i $0,9(80-100 \%)$. Poređenja su vršena između prašumske sastojine bukve i jele (sa smrčom) Ravna vala, zatim, dvoetažne sastojine gdje je evidentirana smjena vrsta drveća (bukva preovladava u nadstojnoj etaži dok je u podmlatku pretežno zastupljena jela) na lokalitetu Medvjeđa lokva i sastojine tipične raznodobne gospodarske šume bukve i jele (sa smrčom) u neposrednoj blizini prašumske sastojine. Prikupljanje podataka je izvršeno metodom totalnog premjera na stalnim eksperimentalnim plohama površime 1 ha u prašumskoj sastojini i dvoetažnoj sastojini na lokalitetu Medvjeđa lokva, te na kružnim plohama poluprečnika 12,62 m. Pozicije eksperimantalnih ploha kružnog oblika određene su sistematskim uzorkom u obliku mreže na sjecištima Gauss-Krügerovog sistema, u razmacima od 100 metara. Mreža je položena u tri transekta po 27 ploha koji se prostiru kroz šumska odjeljenja broj: 111, 113, 114 i 115 gospodarske jedinice „Igman“, lokalitet Ravna vala. Dvije eksperimentalne plohe $\mathrm{u}$ obliku kvadrata površine 1 ha postavljene su, jedna $\mathrm{u}$ prašumskom rezervatu Ravna vala radi očuvanosti sastojine, stanje bez utjecaja čovjeka (odjeljenje 106, GJ „Igman“), a druga u gospodarskoj šumi ovog područja Medvjeđa 
lokva (odjeljenje 117, GJ „Igman”) radi specifične strukture sastojine. Plohe kvadratnog oblika od 1 ha površine podijeljene su mrežom kvadrata 10 x $10 \mathrm{~m}$ na 100 plohica.

Rezultati istraživanja pokazuju da je maksimalan broj jedinki svih uzrasnih kategorija podmlatka jele utvrđen pri stepenu sklopa $0,7-0,9 \mathrm{i}$ omjeru smjese 0,5 bukva : 0,5 jela (smrča). Navedeni uvjeti stepena zastrtosti zemljišta krošnjama stabala i omjera smjese vrsta drveća su optimalni za podmlađivanje jele u istraživanim sastojinama. Analizom podmlađivanja jele u sastojinama različite strukture ustanovljene su statistički značajne razlike između broja jedinki podmlatka jele u različito strukturiranim sastojinama. Povoljni uvjeti za nesmetan rast i razvoj pojedinih uzrasnih kategorija podmlatka jele su u sastojinama različite strukturne izgrađenosti. Optimalne uvjete za pojavu i nesmetan rast i razvoj, za svaku uzrasnu kategoriju podmlatka jele, moguće je obezbijediti formiranjem podmladnih površina na kojima će se u zavisnosti od uzrasta podmlatka, uzgojnim zahvatima izgraditi odgovarajuća struktura sastojine.

Corresponding author: Sead Ivojević, Faculty of Forestry University of Sarajevo; Zagrebačka 20, 71000 Sarajevo, Bosnia and Herzegovina; e-mail address: s.ivojevic@sfsa.unsa.ba 